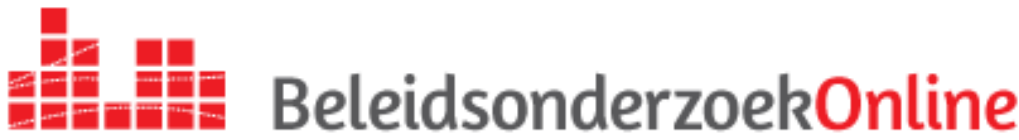

DOI: 10.5553/Beleidsonderzoek.000039

\section{Voorwerking, werking en doorwerking: een praktisch instrument voor het meten van het effect van rekenkamers}

\section{Etienne Lemmens}

Aanbevolen citeerwijze bij dit artikel

Etienne Lemmens, 'Voorwerking, werking en doorwerking: een praktisch instrument voor het meten van het effect van rekenkamers', Beleidsonderzoek Online februari 2014, DOI: 10.5553/Beleidsonderzoek.00oo39

'De theorie is goed en wel, maar de praktijk leert anders.' Sigmund Freud

\section{Samenvatting}

In dit artikel werk ik vanuit de praktijk de parameters uit voor een instrument om het effect van lokale rekenkamers te meten, wat over het algemeen doorwerking wordt genoemd. Daarbij onderscheid ik onderdelen van het rekenkamerwerk als agendering, uitvoering, rekenkamerwerk, rekenkamerproduct en presentatie. De parameters die daaruit volgen, zijn randvoorwaardelijk met betrekking tot het effect van rekenkamerwerk. Aan datzelfde euvel lijdt ook Hoekstra's model van doorwerking (zie Hoekstra, 2013). Om het model voor het meten van het effect van rekenkamers te vervolmaken, moet het verder aangevuld worden. Daarvoor is het noodzakelijk de taak/rol van rekenkamers opnieuw te definiëren. Hier wordt deze opgevat als 'een bijdrage leveren aan de verbetering van de beleidsvorming, besluitvorming en beleidsuitvoering'. De term doorwerking kan daarna met een nieuwe connotatie worden geladen en valt samen met indirect effect van rekenkamers. Tevens kan het effect aangevuld worden met voorwerking en werking. Tot slot presenteer ik de parameters van het instrument teneinde het gehele spectrum van effect van rekenkamers te omvatten.

\section{Inleiding}

Het onderwerp doorwerking is een heikel thema bij lokale rekenkamers. En gezien het soort onderzoeken dat rekenkamers verrichten, zoals naar de effectiviteit van het uitgevoerde gemeentelijke beleid, is het op zijn zachtst gezegd ironisch dat zij nog geen middel hebben ontwikkeld om te meten hoe effectief ze zelf zijn. Tenminste, als we ervan uitgaan dat effectiviteit van het werk van rekenkamers te meten is. Daar kom ik aan het eind van mijn betoog op terug. Doel van dit artikel is de discussie aan te gaan over wat onder effect van rekenkamers begrepen kan worden en een instrument voor te stellen dat het effect van rekenkamers kan meten.

Ronald Hoekstra doet een poging de discussie over doorwerking van 
rekenkamercommissies te voeren (Hoekstra, 2013). Hij start vanuit het theoretische model dat Bekkers et al. in 2004 hebben gepresenteerd over doorwerking van strategische beleidsadviezen (Bekkers et al., 2004).

Hoekstra definieert doorwerking van (lokale) rekenkamer(commissie)s als volgt: 'beïnvloeden van besluitvormingsprocessen door middel van het bieden van toepassingsgerichte kennis op basis van beleidsonderzoek, verricht door of in opdracht van een rekenkamer'. Ik meen dat dit een te beperkte invulling van het begrip doorwerking van rekenkamerwerk is, en niet alle werking die rekenkamers kunnen hebben dekt. Bovendien betwijfel ik of deze deductieve benadering een werkbare definitie van het effect van rekenkamers gaat opleveren, of een instrument om dat te meten. Hoekstra destilleert zes factoren die van invloed zijn op doorwerking of benutting van rekenkameronderzoek: Behoefte van de doelgroep, attitude van de doelgroep, Communicatie naar doelgroep, Kwaliteit van onderzoek, Timing van het onderzoek en Onderwerp van onderzoek (BACKTO). Verschillende aspecten die bij Hoekstra via deze deductieve benadering de revue passeren, zijn hoogstens randvoorwaardelijk voor het effect van rekenkamers.

Ik stel voor om het vraagstuk van het effect van rekenkamers praktischer aan te pakken, dat wil zeggen via een meer inductieve benadering vanuit de praktijk van het rekenkamerwerk. Ik stel dus voor om na te lopen hoe een rekenkamer over het algemeen te werk gaat, en van daaruit handvatten voor het meten van effect te formuleren. Het rekenkamerproces is grosso modo als volgt: agendering, uitvoering, product, presentatie. Bij al deze fasen is interactie en communicatie tussen rekenkamer, onderzoeksobject (ambtenaren en wethouders) en doelgroep (de raad) aan de orde. In de verdere loop van het artikel doe ik voorstellen om aspecten op te nemen in een instrument voor doorwerking en doe ik een suggestie om dat aspect meetbaar te maken. Tot slot worden deze aspecten gebundeld in het instrument.

Voor de goede orde: hier gebruik ik rekenkamer ook voor rekenkamercommissie en raad ook voor provinciale staten, en wethouder ook voor gedeputeerde. Op het rekenkamerwerk op landelijk niveau, de Algemene Rekenkamer, of bij de waterschappen heb ik te weinig zicht om het onderstaande voor die praktijk geldig te verklaren.

\section{Agendering}

Agendering van rekenkamers heeft te maken met timing van onderzoek, de keuze van de onderwerpen en 'voorwerking'. Deze aspecten komen hieronder aan bod.

Rekenkamers kondigen onderzoeken aan, meestal in jaarplannen. En als het onderzoek daadwerkelijk start, wordt dat vaak ook nog gecommuniceerd. Volgens het vraaggestuurde model van doorwerking (zie het demand-pull model van Bekkers et al., 2004) wordt doorwerking verklaard doordat hetgeen de rekenkamer onderzoekt, aansluit bij de behoefte van de gebruiker (de B van het BACKTO-model van Hoekstra). Dat heeft met name te maken met de timing van het onderzoek en de agenda van de raad. Komt de rekenkamer te vroeg of te laat met de resultaten van het onderzoek, dan kan de raad er weinig mee, hoe goed onderzoek, conclusies en aanbevelingen ook mogen zijn. Timing moet dus als aspect worden opgenomen in het instrument.

Het aspect van timing kan worden gemeten door de raadsleden en griffiers daarop te ondervragen en de mening van de rekenkamer te inventariseren. Daarnaast is de vraag of de onderwerpkeuze van de rekenkamer niet alleen qua timing maar ook inhoudelijk overeenkomt met de behoefte van de raad. De rekenkamer is door de wetgever onafhankelijk gepositioneerd in de lokale 
bestuurlijke verhoudingen. Op die onafhankelijkheid hebben rekenkamers zich in de beginfase veel beroepen. De rekenkamer bepaalde zelf wel welke onderwerpen hij onderzocht (zie het aanbodgerichte 'science' model van Bekkers et al., 2004). De raad mag geen opdrachtgever van de rekenkamer zijn, volgens deze benadering. En, natuurlijk moet de rekenkamer onafhankelijk zijn, zijn eigen agenda kunnen bepalen, eigenstandig onderzoek doen, enzovoort. Anders word je al snel een speelbal van de politiek.

Vaak hebben rekenkamers criteria opgesteld op basis waarvan zij besluiten een onderzoeksonderwerp al dan niet op te pakken. De NVRR heeft in 2008 een aantal van deze criteria op een rij gezet (NVRR, 2008). Bij deze criteria gaat het bijvoorbeeld om de grote (financiële) belangen die met het onderwerp zijn gemoeid of spreiding van de onderwerpen. Met een beetje goede wil zijn enkele van de criteria op te vatten als aansluitend bij de behoefte van de raad, zoals 'toegevoegde waarde' of 'bruikbaarheid (inspelen op verzoeken) en verwachte leereffecten'. Expliciet komt de behoefte van de raad echter niet aan bod. De criteria verbieden de rekenkamer evenwel ook niet om te luisteren naar de behoefte van de raad.

Dit aspect kan geoperationaliseerd worden door de raadsleden en griffiers te vragen of de onderwerpkeuze van de rekenkamercommissie aansluit bij de behoefte van de raad, en de mening van de rekenkamer hierover te inventariseren.

Een bijzondere vorm van effect is wat ik 'voorwerking' zou willen noemen. 'Du moment' dat de rekenkamer een onderwerp agendeert, kan een reactie worden waargenomen bij de onderzochte. Nog voordat het onderzoek is gestart, wordt snel een SMART-geformuleerd beleidskader opgesteld en voorgelegd aan de raad, procesverbeteringen doorgevoerd, enzovoort. En in een eventuele bestuurlijke reactie wordt de rekenkamer bedankt voor het waardevolle onderzoek en wordt geconstateerd dat het college en ambtelijk apparaat al lang bezig waren met de, overigens zeer waardevolle, aanbevelingen van de rekenkamer die als steun worden ervaren voor de richting die het college al lang uit wilde. Dit kan frustrerend zijn en overkomen als een negatie van de toegevoegde waarde van de rekenkamer. Als die laatste emotie hoog zit, kan het allicht aanleiding zijn tot een gesprek met college en/of secretaris. Maar het is ook simpelweg een wijze waarop de rekenkamer effect heeft. Alleen al het bestaan van een rekenkamer kan effect sorteren.

Dit is lastig aan te tonen, en, karikaturaal neergezet, je wilt als rekenkamer ook niet vervallen in een puberale wedloop wie als eerste zei dat beleidsvoornemens SMART geformuleerd moesten worden. Voorwerking, als wijze van effect, kan naar mijn smaak het best geoperationaliseerd worden door de mening van de rekenkamer zelf mee te nemen in het meetinstrument voor doorwerking.

\section{Uitvoering}

Met betrekking tot de uitvoering van het rekenkameronderzoek onderscheid ik de aanpak van het onderzoek en de interactie met de omgeving.

Bij de uitvoering van het onderzoek komt het science model om de hoek kijken (zie Bekkers et al., 2004). De rekenkamer onderzoekt op basis van een probleem- en vraagstelling en pakt dat methodisch aan. Dat gebeurt gewoonlijk niet zwaar wetenschappelijk, met bijvoorbeeld controlegroepen en dergelijke.

Het onderzoek en de uitkomsten zijn niet fundamenteel, maar toepassingsgericht. De aanpak is over het algemeen wel methodisch, dat wil zeggen dat deze verantwoord dient te worden, betrouwbare resultaten oplevert en reproduceerbaar is. Dat bepaalt de kwaliteit van het onderzoek, en deze kwaliteit wordt geacht een belangrijke voorwaarde voor de effectiviteit van 
rekenkamers te zijn. De aanbevelingen van de rekenkamer zullen weinig effect hebben als de aanpak en onderzoeksresultaten onbetrouwbaar zijn. Het is evenwel niet zo dat aanbevelingen automatisch worden opgevolgd als de kwaliteit van het onderzoek boven elke twijfel verheven is. Zo konden rekenkamercommissies zich in het begin van hun bestaan afvragen, hoe het kon dat de raad niets deed met het uitmuntende rekenkameronderzoek, met onomstotelijke bevindingen en conclusies, en aanbevelingen die daaruit onontkoombaar volgden. In het aanbodgerichte model of science model (zie Bekkers et al., 2004) is hiervoor geen verklaring te vinden. Hoewel kwaliteit van het onderzoek belangrijk is, spelen bij effectiviteit dus meer aspecten een rol. De operationalisering van kwaliteit van de uitvoering als aspect van efectiviteit betreft vragen als: heeft de rekenkamer de juiste aanpak gekozen om het voorliggende vraagstuk te onderzoeken en is de gekozen aanpak methodisch en verantwoord uitgevoerd? Voor veel raadsleden zijn dit vaak moeilijk te beantwoorden vragen, vandaar dat ik voorstel dit item via een peer review of visitatie te laten beoordelen. Aanmoedigingsprijzen, zoals de Goudvink van de NVRR, kunnen hierbij trouwens ook behulpzaam zijn. Sinds vorig jaar is doorwerking expliciet als toekenningscriterium voor deze prijs opgenomen. De kwaliteit van het onderzoek kan nog verder verdiept of geoperationaliseerd worden door subcriteria op te nemen als: toepasbaarheid en validiteit van kwantitatieve of kwalitatieve onderzoekstechnieken, er is een onderzoekslogboek bijgehouden, enzovoort.

Een tweede element bij de uitvoering van het onderzoek betreft de interactie met de onderzochte en de doelgroep. Hier speelt een oude reflex met betrekking tot de onafhankelijkheid van de onderzoeker. Tot een aantal jaar geleden was interactie tussen onderzoeker en object en/of gebruiker 'verdacht'. Gechargeerd gesteld ging dat als volgt: als iemand met een probleem zit, en een deskundige blik op de werkelijkheid nodig heeft, vraagt hij/zij om onderzoek. Dan komt een onderzoeker in beeld, die zegt: 'Ik ben de beheerder van de zuiver wetenschappelijke methode, en elke interferentie met het onderzoek, door wie dan ook, verstoort het proces en bevlekt het eindresultaat. Dus, laat me in alle onafhankelijkheid en rust mijn werk doen en ik breng je over 4 maanden de analyse en als het meezit ook oplossingsrichtingen.'

Het is in de sociale wetenschappen al lastig om interactie te vermijden. Dan heb je bijvoorbeeld als historicus nog het voordeel dat de meeste onderzochten al dood en begraven zijn en niet kunnen interfereren met de uitvoering van het onderzoek, uitgezonderd wellicht door middel van een seance. Maar als rekenkamer functioneer je in een bestuurlijke context, en dan ook nog eens in een politiek gevoelige setting. Interactie met de onderzochte is onvermijdelijk: je vraagt stukken op, neemt interviews af, doet een feitencheck, enzovoort. Er zijn talloze manieren en momenten waarop interactie en beïnvloeding plaatsvinden. De rekenkamer moet er op die momenten voor waken dat de interactie niet ten koste gaat van de kwaliteit of 'zuiverheid' van de onderzoeksuitvoering. Maar, interactie kan positief zijn, ook tijdens de uitvoering van het onderzoek. Zo kun je bijvoorbeeld vooraf aan het eigenlijke onderzoek, in overleg met ambtenaren en/of wethouder tot een gezamenlijk gedragen normenkader komen. Rekenkamers kunnen interactie ook tot onderdeel van de onderzoeksaanpak opwaarderen, bijvoorbeeld door een werkconferentie met ambtenaren of een rondetafelgesprek met ambtenaren en burgers te organiseren om de bevindingen te bespreken. Dat zijn manieren voor de rekenkamer om gedurende de uitvoering van het onderzoek al aan acceptatie van de resultaten, conclusies en aanbevelingen te werken (zie ook het interactiemodel van Bekkers et al., 2004). 
Dit aspect is randvoorwaardelijk en kan het best beoordeeld worden door een peer review of visitatie, bij voorkeur aangevuld met de mening van de ambtenaren, wethouders, raadsleden en eventueel burgers die bij de interactie zijn betrokken.

\section{Rekenkamerproduct}

Met betrekking tot het product van de rekenkamer wil ik een onderscheid maken naar analyse en vorm.

In het product legt de rekenkamer verantwoording af over de uitvoering van het onderzoek, dus over de wijze waarop de rekenkamer aan de bevindingen is gekomen. In het rekenkamerproduct komt dan ook een belangrijk

kwaliteitsaspect aan bod, namelijk de analyse. Dit aspect ligt dicht bij het science model van doorwerking van Bekkers et al., 2004. Het gaat er hierbij om of de conclusies logisch volgen uit de bevindingen. Voordat de rekenkamer conclusies trekt, is het gebruikelijk de bevindingen te laten controleren door middel van een feitencheck of hoor en wederhoor, over het algemeen ambtelijke hoor en wederhoor genoemd. De rekenkamer kan op basis van de feitencheck bevindingen aanpassen en dan wordt in principe de fase van waarheidsvinding afgesloten.

Daarna formuleert de rekenkamer de conclusies, die logisch moeten voortvloeien uit de bevindingen. Door middel van de conclusies beantwoordt de rekenkamer in ieder geval de onderzoeksvragen waarmee het onderzoek is gestart. Indien de onderzoeksvragen niet volledig of adequaat beantwoord kunnen worden, legt de rekenkamer uit waardoor dat komt. Dat kan bijvoorbeeld liggen aan een verkeerd gekozen onderzoeksaanpak, informatie of bescheiden die niet aangeleverd zijn, enzovoort.

Op basis van de beantwoording van de onderzoeksvragen formuleert de rekenkamer over het algemeen aanbevelingen. Deze aanbevelingen kunnen gericht zijn aan ambtenaren, college en/of de raad. De rekenkamer ondersteunt weliswaar de raad in diens kaderstellende en controlerende taken, maar kan ook zaken tegenkomen die ambtenaren en college verder kunnen helpen. De raad kan in het dualistisch bestel vaak weinig met aanbevelingen die in de invloedssfeer van college of secretaris liggen. De raad heeft doorgaans geen middelen of mogelijkheden om de implementatie van dat soort aanbevelingen te monitoren en zou dat ook niet moeten willen, bestuurstechnisch gezien. Dan is het wel zo handig als de rekenkamer vermeldt aan wie welke aanbeveling is gericht, zodat de reikwijdte ervan voor alle partijen duidelijk is.

Bij veel rekenkamers worden de conclusies en aanbevelingen ook nog een keer door een bestuurlijke hoor en wederhoor gehaald. Een aantal rekenkamers, waaronder die waar ik voorzitter van ben, laat dat na. De opbrengst van de bestuurlijke hoor en wederhoor is vaak mager of het is een reprise van de feitencheck, opgesteld door de ambtenaar die zijn of haar gram wil halen vanwege punten die na de ambtelijke hoor en wederhoor niet door de rekenkamer werden overgenomen. Maar er is ook een inhoudelijk argument voor rekenkamers om de fase van bestuurlijke hoor en wederhoor over te slaan. Namelijk dat de discussie over de aanbevelingen niet tussen college en rekenkamer moet plaatsvinden, maar in de politieke arena van de raadszaal tussen college en raad. Met de bestuurlijke hoor en wederhoor bestaat de kans dat de politieke discussie wordt doodgeslagen, en dat komt de kwaliteit van de menings- en besluitvorming niet ten goede.

Overigens, wij hebben in onze rekenkamers de bestuurlijke hoor en wederhoor niet helemaal afgezworen, maar door de raad als facultatief laten opnemen in de verordening. Ik kan me voorstellen dat er zeer gevoelige onderwerpen zijn 
waarbij het handig is dat de raad bij de publicatie van het rekenkamerproduct meteen beschikt over de reactie van het college.

Het oordeel of de analyse goed in elkaar steekt, dus of de trits bevindingen, conclusies en aanbevelingen logisch op elkaar volgen, kan goed gegeven worden door gebruikers en/of op basis van een peer review.

Een tweede deelaspect van het product geldt de vorm. De laatste jaren zien we innovatie in de vorm waarin het rekenkamerproduct verschijnt. Niet alleen dikke rekenkamerrapporten, maar ook presentaties in powerpoint of zelfs prezi, checklists, beslisbomen, roadmaps, cartoons, films enzovoort. De vorm waarin het rekenkamerproduct wordt aangeboden, moet de boodschap ondersteunen en voor de doelgroep toegankelijk zijn. Dit aspect valt onder het verspreidingsmodel van doorwerking ( zie Bekkers et al., 2004), waaronder ook timing valt. Het betreft namelijk activiteiten van de rekenkamer om de aanbevelingen zo goed mogelijk onder de aandacht te brengen van de gebruiker. Of de vorm van het rekenkamerproduct de boodschap adequaat ondersteunt, kan heel goed door de gebruikers, raadsleden en griffiers beoordeeld worden, mogelijk aangevuld met een peer review.

Terzijde: zoals gezegd is er innovatie wat betreft de vorm en ik verwacht dat we nog maar pas aan het begin staan van een ontwikkeling die niet alleen de vorm van het rekenkamerproduct, maar ook het werk van de rekenkamer zelf zal veranderen. In de participatiesamenleving die in verband met de decentralisaties wordt nagestreefd, wordt meer en meer verwacht van de burger. Deze moet zelfredzamer worden; meedoen aan de civil society wordt de norm. De burger zal van zijn kant meer en meer inspraak en directe invloed verlangen, zowel op het punt van de politieke besluitvorming als de uitvoering van de arrangementen die hem/haar moeten ondersteunen om actief deel te nemen aan de samenleving. De overheid zal daar alert en open op moeten reageren. Dat vraagt wat van het lokale bestuur, maar ook van de rekenkamer als onderdeel van de lokale democratie. De rekenkamer zal zich moeten bezinnen op zijn rol, en zal mijns inziens een schakel moeten vormen in de verantwoording van het lokale bestuur en de beleidsuitvoerders naar de burger toe. Het is ondenkbaar dat moderne media geen rol zullen spelen in deze innovatie van het publieke toezicht. En, laten we het maar eens polemisch stellen, de vraag of rekenkamers bij die trend kunnen aanhaken, zou wel eens bepalend kunnen zijn voor de vraag of zij 2025 halen.

\section{Presentatie}

Het rekenkamerproduct moet nog verspreid worden om ervoor te zorgen dat de aanbevelingen de juiste aandacht krijgen, zie het verspreidingsmodel van Bekkers et al., 2004. Dat heeft voor een deel te maken met timing en vorm (zie hiervoor), maar ook met communicatie. En dat gaat verder dan een persbericht sturen naar de gebruikelijke media als het rekenkamerproduct gereed is. De boodschap moet optimaal en actief ondersteund worden om opgemerkt te worden door de raad, college, ambtenaren, eventueel betrokken instellingen en burgers.

Niet ieder rekenkamerproduct of aanbeveling leent zich voor ruime verspreiding. Een onderzoek naar een onderwerp als tijdigheid en relevantie van de informatievoorziening aan de raad hoeft niet breed in de pers uitgemeten te worden, maar kan alsnog goed verspreid en begeleid worden door de rekenkamer om de aanbevelingen optimaal te laten landen bij de raad en het ambtelijk apparaat. Dus, afhankelijk van de politieke of maatschappelijke gevoeligheid van het onderwerp, de lading van het rekenkamerproduct en de 
soort gebruiker moeten rekenkamers nadenken over de manier waarop de boodschap het best begeleid en uitgedragen kan worden.

De verspreidingsvorm heb je overigens niet altijd zelf in de hand, de media hebben zo hun eigen, soms ondoorgrondelijke beweegredenen om iets te publiceren. De rekenkamer kan de boodschap in ieder geval actief aanbieden. Zo noemen Bekkers et al. bij verspreiding ook artikelen in (wetenschappelijke) tijdschriften. Dat helpt zeker bij het imago van de rekenkamer als betrouwbaar orgaan en zal allicht op de lange termijn indirect bijdragen aan doorwerking, conform het science model van Bekkers et al. Maar het draagt bij de doelgroep waarschijnlijk weinig direct bij aan acceptatie van aanbevelingen van rekenkamers. Als plaatsing van een artikel over een rekenkameronderzoek in een (wetenschappelijk) tijdschrift lukt, moet je het als rekenkamer overigens zeker niet nalaten.

Tekenend voor de mate van effectiviteit van rekenkamers in relatie tot presentatie en verspreiding is de mate en toon of kleur waarop over de aanbevelingen of product van de rekenkamer geschreven wordt in beleidsnotities van de gemeente en/of instellingen die gemeentelijk beleid uitvoeren, of hoe deze genoemd worden in de media. Alleen maar geciteerd worden, wil overigens nog niet zeggen dat er doorwerking is in de zin dat er ook echt wordt geluisterd naar de rekenkamer. Fixatie op citaties en indexen is gevaarlijk, weten we helaas door de hedendaagse schandalen in de wetenschap. De presentatie, of verspreiding van het product en de aanbevelingen van de rekenkamer, kan mijns inziens het best beoordeeld worden door de gebruikers zelf, raad en griffier, eventueel aangevuld met een peer review.

Hiermee hebben we vanuit de praktijk een aantal aspecten benoemd die in een model of instrument voor effectiviteit van rekenkamers opgenomen kunnen worden. Voordat het instrument gepresenteerd wordt, ga ik hieronder in op de definitie van doorwerking. Daaraan voorafgaand moet ik eerst de taak van de rekenkamer definiëren.

\section{Rol/taak rekenkamer}

In zijn stuk over maatschappelijke effecten van rekenkamers beschrijft Hanemaayer een aantal rollen en functies van rekenkamers zoals hij die is tegengekomen (Hanemaayer, 2012). Dat zijn:

- de functie van de rekenkamer voor de kaderstellende rol van de gemeenteraad;

- de betekenis van het rekenkamerwerk voor wettelijke en volksvertegenwoordigende taken van de gemeenteraad;

- de betekenis van het rekenkamerwerk voor de (gemeentelijke) verantwoording aan de inwoners van de gemeente;

- de positie die de rekenkamer inneemt op het continuüm afrekenen tot leren;

- de adviserende rol van de rekenkamer;

- de rol van de rekenkamer in het bereiken van transparant bestuur. 
effecten van rekenkamerwerk zouden moeten zijn. Hij geeft daarbij een visie waarbij de rekenkamer een rol heeft in enerzijds advies over

bestuursprogramma en beleidsnota's, en anderzijds monitoring van en ex post onderzoek op de uitvoering. Met name voor het eerste stuk, de adviesrol van de rekenkamer, zal Hanemaayer niet alle handen op elkaar krijgen. Op basis van een strikte lezing van de wettelijke taak van de lokale rekenkamer zou je kunnen opmaken dat de rekenkamer zich niet mag bemoeien met de voorkant van het beleidsproces. De rekenkamer zou zijn controlerende rol niet kunnen vervullen als deze aan de voorkant adviseert, onder verwijzing naar het gezegde dat 'de slager zijn eigen vlees niet kan keuren'.

Dat is evenwel schijn. De rekenkamer maakt geen politieke keuzen, dat is voorbehouden aan de gekozen volksvertegenwoordigers in de raad. Wel kan de rekenkamer heel goed vooraf de beleidskeuzen duiden, alternatieven op een rij zetten en consequenties van keuzen helder maken voor raadsleden. Tevens kan de rekenkamer vooraf randvoorwaarden voor een goede monitoring en ex post evaluatie in de besluitvorming inbrengen. En dat kan allemaal zonder dat de rekenkamer zich committeert aan politieke keuzen die een onafhankelijke en adequate monitoring of evaluatie in de weg zouden staan. In de praktijk heeft de rekenkamer in veel gemeenten al een dergelijke 'adviserende' rol opgepakt of gekregen van de raad.

De taak van de rekenkamer zou ik in brede zin als volgt willen definiëren:

De rekenkamer draagt bij aan de verbetering van de beleidsvorming, besluitvorming en beleidsuitvoering door en/of namens het gemeentebestuur.

Ook al vertrekt de rekenkamer vanuit een strikte interpretatie van de wet en verricht hij alleen ex post onderzoek, dan past deze definitie ook goed op deze rekenkamer. Want in ex post evaluaties worden vaak ook aanbevelingen gedaan die zijn gericht op de verbetering van de voorkant van het beleidsproces. De rekenkamer vervult die taak op basis van toepassingsgericht onderzoek. Dan kunnen we doorwerking opvatten als het effect dat de rekenkamer heeft als zijn onderzoeksproduct bijdraagt aan de verbetering van de beleidsvorming, besluitvorming en beleidsuitvoering door en/of namens het gemeentebestuur.

Terzijde: door 'namens het gemeentebestuur' in de definitie op te nemen hebben we, met het oog op de te decentraliseren taken in het sociale domein, ook meteen de gemeenschappelijke regelingen en PPS-constructies meegenomen. Dit in de veronderstelling dat minister Plasterk de belofte van eind oktober 2013 nakomt om het democratische controlegat bij bovenlokale samenwerkingsverbanden te verhelpen. De NVRR heeft een voorbeeldmotie aan de aangesloten leden rondgestuurd om het controlegat te dichten.

De vraag is nu of de hiervoor behandelde parameters dan iets zeggen over doorwerking zoals bedoeld in deze definitie. Veel van de parameters zijn helaas slechts voorwaardelijk. Zij zeggen wel iets over de kwaliteit van het product of het proces van het rekenkameronderzoek, maar zoals eerder gezegd hoeft dat nog niets te zeggen over de feitelijke doorwerking van de rekenkamer. En nu was ik begonnen door te zeggen dat ik bang was dat Hoekstra's deductieve aanpak slechts randvoorwaardelijke parameters zou opleveren. Klopt, ik trap in dezelfde valkuil. Ook al is de timing van het onderzoek goed, de uitvoering van het onderzoek kwalitatief onomstreden, het product zeer toegankelijk en de presentatie glad verlopen, dan nog hoeft er geen sprake te zijn van doorwerking 
in de zin van bovenstaande definitie. Rekenkamers zitten in een politieke omgeving, zijn georganiseerd rond een podium waarop maatschappelijk tegengestelde belangen hun kristallisatiepunt vinden. Het rekenkamerwerk en product gaan bij publicatie onderdeel uitmaken van het betoog in de politieke arena, of het politieke 'discours'. Je kunt dan als rekenkamer aan alle kwalitatieve voorwaarden hebben voldaan, maar dat hoeft niet automatisch te leiden tot verbetering van de besluitvorming of het door of namens het gemeentebestuur gevoerde beleid. Op zijn best zijn de meeste parameters dus 'circumstantial evidence' voor het effect van een rekenkamer.

Zeggen de parameters dan niets? Toch wel, want andersom gaat de redenering namelijk niet snel op. Als de rekenkamer zich geen rekenschap geeft van kwaliteit en een slecht rapport oplevert, is de kans bijna nihil dat er doorwerking is. Bijna nihil, want ik schat de kans niet geheel op o, dat de strijd in de politieke arena er wel eens voor zou kunnen zorgen dat een zwaar ondermaats rekenkamerproduct toch effect sorteert.

\section{Voorwerking, werking en doorwerking}

Terug naar het praktische instrument om effect van rekenkamers inzichtelijk en meetbaar te maken. Effectiviteit is mijns inziens een optelsom van de scores op de hierboven behandelde aspecten of parameters. Met de definitie in het achterhoofd is de lijst van parameters nog verder aan te vullen. Daarvoor moet ik terug naar het werk van Bekkers et al. Deze onderscheiden met betrekking tot strategische beleidsadviezen vier vormen van doorwerking: instrumenteel, conceptueel, agenderend en politiek-strategisch. Kort resumerend:

- Instrumentele doorwerking leidt tot een directe verandering in gedrag van individuen of organisatie.

- Conceptuele doorwerking is indirect, een lange termijn wijziging van kennis, opvattingen of redeneringen van individuen of organisatie.

- Agenderende doorwerking is het op de agenda zetten van een nieuw beleidsthema of maatschappelijk debat.

- Politiek-strategische doorwerking geldt de versterking van de machtspositie van één of enkele spelers om politieke doelen te realiseren.

Deze laatste vorm van doorwerking is volgens mij niet van toepassing op het werk van rekenkamers. Rekenkamers streven geen politieke doelen na, waardoor de politiek-strategische vorm van doorwerking zich beperkt tot de wereld van strategische beleidsadviezen. Die laat ik hier dan ook buiten beschouwing. De agenderende vorm heb ik al grotendeels meegenomen in 'voorwerking'. De agenderende vorm van doorwerking, namelijk het op de agenda plaatsen van een nieuw onderwerp, kan zeker bijdragen aan het doel om de beleidsvorming, besluitvorming en beleidsuitvoering door en/of namens het gemeentebestuur te verbeteren. Bovendien heeft het naakte bestaan van een rekenkamer vaak al voorwerking in de bedoelde zin. Dan resten er de instrumentele (directe) en conceptuele (indirecte) vormen van doorwerking. Berenschot heeft in de evaluatie van decentrale rekenkamers deze twee vormen van doorwerking als volgt gedefinieerd (zie Van der Mark et al., 2011). Instrumentele doorwerking is de concrete doorwerking van afzonderlijke 
rekenkameronderzoeken in het beleid. Conceptuele doorwerking is er volgens Berenschot als college en ambtelijk apparaat rekening houden met of geleerd hebben van het fenomeen rekenkamer. Beide vormen van doorwerking zijn moeilijk te operationaliseren als de taak van de rekenkamer er niet in betrokken wordt, zie de definitie hiervoor. Daarnaast is conceptuele doorwerking relatief diffuus uitgewerkt en moeizaam te operationaliseren. Waarschijnlijk houdt elk college en ambtelijk apparaat rekening met het fenomeen rekenkamer, als deze aanwezig is in de lokale topografie. Dat komt overeen met de zojuist omschreven voorwerking.

Ik stel een iets andere benadering van de instrumentele en conceptuele vorm van doorwerking voor. Daarbij maak ik onderscheid tussen enerzijds werking, als direct effect van het werk van de rekenkamer, en anderzijds doorwerking, als indirect effect van het werk van de rekenkamer. De rekenkamer heeft werking, een direct effect, als de aanbevelingen worden overgenomen. Dat is wat Bekkers et al. noemen als signaal voor de instrumentele vorm van doorwerking, namelijk het aantal of percentage overgenomen aanbevelingen. Degenen die al een tijdje meelopen in rekenkamerland, zullen meteen opmerken dat dit weliswaar een hard gegeven is, maar dat dit nog niet wil zeggen dat de aanbeveling daarmee is geïmplementeerd of wordt nageleefd, dus daadwerkelijk effect heeft gehad. Het is vaak een mantra van colleges om te melden dat ze de uiterst waardevolle aanbevelingen van de rekenkamer overnemen. Of er daarna iets mee gebeurt, is nog maar de vraag. Soms hangt implementatie en naleving af van het feit of de rekenkamer na verloop van tijd een vervolgonderzoek opstart. De werking van rekenkamers zou nader gespecificeerd kunnen worden met 'overgenomen, geïmplementeerde en nageleefde aanbevelingen'.

Het best is de werking als direct effect na te gaan door raadsleden, griffiers, ambtenaren en/of wethouders te vragen naar de mate waarin aanbevelingen zijn overgenomen en geïmplementeerd. De mening van de rekenkamer kan daarbij geïnventariseerd worden. Als meetbaar criterium kan aantal en/of percentage overgenomen en geïmplementeerde aanbevelingen daaraan toegevoegd worden. De rekenkamer heeft doorwerking, dus indirect effect, als er op de lange termijn wijzigingen in kennis, opvattingen en redeneringen van individuen en organisatie zijn te constateren die bijdragen aan de verbetering van de beleidsvorming, besluitvorming en beleidsuitvoering door en/of namens het gemeentebestuur. Dat maakt het meteen lastig te meten. Het gaat hier om lange termijn wijzigingen, en die zijn niet makkelijk te herleiden tot specifieke rapporten of aanbevelingen van rekenkamers. Wat je in ieder geval kunt constateren, is dat, wanneer een rekenkamer in tien opeenvolgende rapporten aanbeveelt dat de beleidsdoelstellingen SMART geformuleerd moeten worden, de rekenkamer weinig doorwerking heeft. Het gaat bij doorwerking om het bijdragen aan sensitiviteit en opvattingen bij de gemeente op het gebied van onderwerpen en werkwijzen die de lokale beleidsvorming, besluitvorming en beleidsuitvoering verbeteren. Dat is niet direct tastbaar in een meetbare parameter, zoals overgenomen en geïmplementeerde aanbevelingen. Bovendien is de rekenkamer daarbij afhankelijk van het adaptatie- en leervermogen van individuen en organisatie. Om ervoor te zorgen dat de rekenkamer doorwerking heeft, moet deze bij het onderzoeksproces en onderzoeksproduct rekening houden met de receptiviteit van de aanbevelingen bij de gemeentelijke organisatie.

Mijns inziens is doorwerking als indirect effect na te gaan door raadsleden, griffiers, ambtenaren en/of wethouders te vragen naar de indirecte en lange termijn effecten van het rekenkamerwerk. Ook hierbij kan de mening van de rekenkamer meegenomen worden. 
Resumerend heeft de rekenkamer de volgende bijdrage aan de verbetering van de beleidsvorming, besluitvorming en beleidsuitvoering door en/of namens het gemeentebestuur:

- voorwerking: de agenderende functie van de rekenkamer, alleen al door het bestaan van de rekenkamer of agenderen van specifieke onderzoeksonderwerpen;

- werking: directe verbetering door overname, implementatie en naleving van de aanbevelingen van de rekenkamer;

- doorwerking: indirecte verbetering door lange termijn wijziging van kennis, opvattingen en redeneringen van individuele ambtenaren en wethouders en gemeentelijk bestuur.

\section{Instrument}

Daarmee komen we tot slot bij het instrument om het effect te meten dat rekenkamers nastreven in het lokale bestel. Daar wil ik meteen een voorbehoud bij maken. In zijn oratie in 1882 stelde de latere Nobelprijswinnaar Heike Kamerlingh Onnes dat hij boven elk fysisch laboratorium de spreuk 'Door meten tot weten' wilde beitelen. Deze spreuk is helaas in het snelle managementjargon verworden tot 'meten is weten'. Dat is echter een weinigzeggend credo, want als je iets meet, weet je eigenlijk nog bar weinig. Eén meter bijvoorbeeld is groot voor een zakdoek, maar klein voor een oceaanstomer. Zonder context kun je de meting plaatsen noch duiden. Als je je echter wel bewust bent van de context, kun je heel goed meten en daarmee tot kennis komen.

Dit voorbehoud gemaakt hebbende, stel ik voor de werking en doorwerking van rekenkamers in het instrument bij de taak van de rekenkamer op te nemen, namelijk bijdragen aan de verbetering van de beleidsvorming, besluitvorming en beleidsuitvoering door en/of namens het gemeentebestuur. Uiteindelijk kom ik dan tot onderstaand voorstel voor een instrument om het effect van rekenkamers te concretiseren en uiteindelijk te vertalen in een meetinstrument.

Figuur 1 Instrument voor het effect (voorwerking, werking en doorwerking) van rekenkamers

\begin{tabular}{|l|l|l|l|}
\hline & Aspect & Wat & Hoe \\
\hline Taak & $\begin{array}{l}\text { Verbetering van } \\
\text { beleidsvorming, } \\
\text { besluitvorming en } \\
\text { beleidsuitvoering } \\
\text { door en/of } \\
\text { namens het } \\
\text { gemeentebestuur }\end{array}$ & $\begin{array}{l}\text { Werking of } \\
\text { (directe) } \\
\text { beïnvloeding } \\
\text { gedrag van } \\
\text { individuen en } \\
\text { organisatie }\end{array}$ & $\begin{array}{l}\text { Raadsleden, griffiers, } \\
\text { ambtenaren, } \\
\text { wethouders bevragen, } \\
\text { mening rekenkamer }+ \\
\text { aantal of percentage } \\
\text { geïmplementeerde } \\
\text { aanbevelingen }\end{array}$ \\
\hline & $\begin{array}{l}\text { Doorwerking of } \\
\text { indirecte) } \\
\text { beïnvloeding } \\
\text { kennis, opvattingen } \\
\text { en werkwijzen } \\
\text { individuen en } \\
\text { organisatie }\end{array}$ & $\begin{array}{l}\text { ambtenaren, } \\
\text { aethouders bevragen, } \\
\text { mening rekenkamer }\end{array}$ \\
\hline
\end{tabular}




\begin{tabular}{|c|c|c|c|}
\hline Agendering & Timing & $\begin{array}{l}\text { Samenloop met de } \\
\text { agenda van de raad }\end{array}$ & $\begin{array}{l}\text { Raadsleden en } \\
\text { griffiers bevragen, } \\
\text { mening rekenkamer }\end{array}$ \\
\hline & Onderwerpkeuze & $\begin{array}{l}\text { Rekening gehouden } \\
\text { met de behoefte } \\
\text { van de raad }\end{array}$ & $\begin{array}{l}\text { Raadsleden en } \\
\text { griffiers bevragen, } \\
\text { mening rekenkamer }\end{array}$ \\
\hline & Voorwerking & $\begin{array}{l}\text { Agendering leidt tot } \\
\text { gedragsverandering }\end{array}$ & Mening rekenkamer \\
\hline \multirow[t]{2}{*}{ Uitvoering } & Aanpak & $\begin{array}{l}\text { De juiste methode } \\
\text { om het vraagstuk te } \\
\text { onderzoeken }\end{array}$ & $\begin{array}{l}\text { Peer review of } \\
\text { visitatie of } \\
\text { aanmoedigingsprijzen }\end{array}$ \\
\hline & Interactie & $\begin{array}{l}\text { Communicatie en } \\
\text { interactie met } \\
\text { ambtenaren, } \\
\text { wethouders, } \\
\text { raadsleden en } \\
\text { burgers tijdens } \\
\text { onderzoek }\end{array}$ & $\begin{array}{l}\text { Peer review of } \\
\text { visitatie, aangevuld } \\
\text { met ambtenaren, } \\
\text { wethouders, } \\
\text { raadsleden en burgers } \\
\text { bevragen }\end{array}$ \\
\hline \multirow[t]{2}{*}{ Product } & Analyse & $\begin{array}{l}\text { Bevindingen volgen } \\
\text { uit de aanpak, de } \\
\text { conclusies volgen } \\
\text { uit de bevindingen, } \\
\text { de aanbevelingen } \\
\text { volgen uit de } \\
\text { conclusies }\end{array}$ & $\begin{array}{l}\text { Raadsleden en } \\
\text { griffiers bevragen, } \\
\text { peer review of } \\
\text { visitatie }\end{array}$ \\
\hline & Vorm & $\begin{array}{l}\text { De gekozen vorm } \\
\text { ondersteunt } \\
\text { optimaal inhoud en } \\
\text { boodschap }\end{array}$ & $\begin{array}{l}\text { Raadsleden en } \\
\text { griffiers bevragen, } \\
\text { peer review of } \\
\text { visitatie }\end{array}$ \\
\hline Presentatie & Verspreiding & $\begin{array}{l}\text { De verspreiding } \\
\text { ondersteunt } \\
\text { optimaal de } \\
\text { boodschap }\end{array}$ & $\begin{array}{l}\text { Peer review of } \\
\text { visitatie, aangevuld } \\
\text { met ambtenaren, } \\
\text { wethouders, } \\
\text { raadsleden en burgers } \\
\text { bevragen }\end{array}$ \\
\hline
\end{tabular}

Daar waar feitelijke documentatie voorhanden is, afkomstig uit bijvoorbeeld jaarverslagen van de gemeente of vervolgonderzoeken of evaluaties van de rekenkamer, kan en moet dat uiteraard opgenomen worden in het instrument. Dit model ontbeert helaas de charme van een acroniem zoals dat van Hoekstra's BACKTO. TAUPP of VTOVAIAVV is het niet helemaal, dus een klinkend acroniem zit vooralsnog niet in dit model.

Het instrument is waarschijnlijk het meest geschikt op het niveau van het individuele rekenkamerproduct. Een rekenkamer heeft werking of doorwerking door specifieke aanbevelingen. Toepassing van het instrument lijkt het best te kunnen plaatsvinden in het kader van een visitatie of peer review. Het is overigens wel een ander instrument dan een visitatie of evaluatie, maar kan er onderdeel van uitmaken. De commissie kwaliteitszorg van de NVRR komt op korte termijn met een model voor onderlinge visitatie van rekenkamers. Discussie, aanvullingen, verbeteringen en suggesties met betrekking tot het 
instrument zijn uiteraard welkom. Rest nog het instrument nader in te vullen. Per item onder 'wat' kunnen één tot drie vragen opgenomen worden die aan de groepen onder 'hoe' gesteld kunnen worden. De gecombineerde score op deze twintig tot dertig items zouden dan zicht moeten geven op de (door)werking van een rekenkamer en daarmee de bijdrage die deze heeft aan de verbetering van de beleidsvorming, besluitvorming en beleidsuitvoering door en/of namens het gemeentebestuur.

\section{Literatuur}

Bekkers, V., et al. (2004). Doorwerking van Strategische Beleidsadvisering. EUR/UvT.

Hanemaayer, D. (2012). Onderzoek door lokale rekenkamers: maatschappelijke effecten versus beleidstechniek. Beleidsonderzoek Online april 2012.

DOI:10.5553/Beleidsonderzoek.000002

Hoekstra, R. (2013). Wat is de meerwaarde van onze rekenkamer? Introductie van een model om de doorwerking van rekenkameronderzoek te meten.

Beleidsonderzoek Online oktober-december 2013.

DOI:10.5553/Beleidsonderzoek.000025

Mark, R van der, et al. (2011). Evaluatie van de provinciale en gemeentelijke rekenkamers. Den Haag: BZK/Berenschot.

NVRR. (2008). Handreiking onderzoek lokale Rekenkamers \& Rekenkamercommissies. Nijkerk. 